\title{
PENAMBAHAN JUS DAUN SIRIH (Piper betle Linn) PADA RANSUM AYAM PETELUR TERHADAP PENURUNAN KOLESTEROL TELUR
}

\author{
Ahmad Khoirul ${ }^{1)}$, Edya Moelia Lubis ${ }^{2)}$ \\ ${ }^{1)}$ Mahasiswa Program Studi Ilmu Ternak Fakultas Peternakan \\ ${ }^{2)}$ Dosen Program Studi Ilmu Ternak Fakultas Peternakan \\ Universitas Islam Balitar \\ Jl. Majapahit No. 04 Kota Blitar
}

\begin{abstract}
The purpose of this study was to determine the volume increase in betel leaf juice ration of laying hens egg cholesterol reduction. This study uses layer laying hens period of 250 heads aged 50 weeks from Isa Brown strain. The method used is an experimental method that consists of five treatments and five repetitions, and each repeat consists of 10 of chicken with P0 treatment (basal feed), P1 (basal feed $+5 \mathrm{ml}$ juice of betel leaves), P2 (basal feed $+7.5 \mathrm{ml}$ juice of betel leaves), P3 (basal feed $+10 \mathrm{ml}$ juice of betel leaves), and P4 (basal feed $+12.5 \mathrm{ml}$ juice of betel leaves). Data using analysis with Analysis of Varience (ANOVA) if significant level using by Duncan test. The results showed that addition of betel leaf juice in the diet of laying chickens highly significant effect $(\mathrm{P}<0.01)$ to decrease cholesterol eggs with the best volume is $12.5 \mathrm{ml}$ (P4) as shown by the higher volume of betel leaf juice added to feed laying hens is the higher the tendency of decrease cholesterol eggs. Recommended the addition of juice of betel leaves effectively using $12.5 \mathrm{ml}$ in volume decrease cholesterol eggs.
\end{abstract}

Keywords: juice of betel leaf, laying hens and egg cholesterol.

\section{PENDAHULUAN}

Telur merupakan produk pangan hewani asal ternak yang bernutrisi tinggi, disukai masyarakat, mudah didapat, harga terjangkau dan dapat dibuat berbagai produk olahan seperti roti dan kue. Namun dalam kenyataanya banyak faktor yang menjadi kendala dalam mengkonsumsi produk tersebut, salah satunya adalah kandungan lemak dan kolesterol.

Kolesterol sangat dibutuhkan oleh tubuh manusia sebagai bahan pokok untuk memelihara dinding sel dan fungsi fisiologis lain. Kolesterol dalam zat makanan yang dikonsumsi dapat meningkatkan kadar kolesterol dalam darah, sejauh pemasukan ini masih seimbang dengan kebutuhan tubuh akan tetap sehat. Tetapi banyak orang memasukan kolesterol lebih dari yang diperlukan yaitu dengan makan makanan yang mengandung lemak yang kaya akan kolesterol dalam jumlah yang berlebihan (Soeharno, 2002). Beberapa penyakit yang disebabkan kolesterol diantaranya arterosklerosis, yaitu proses pengapuran dan pengerasan dinding pembuluh darah terutama di jantung, otak, ginjal dan mata. Akibat penyakit ini saluran pembuluh darah khususnya pembuluh darah koroner menjadi sempit dan menghalangi aliran darah didalamnya. Keadaan ini telah terbukti dapat meningkatkan resiko penyakit jantung koroner dan pada otak bisa menyebabkan penyakit strok. Untuk menurunkan kelebihan kolesterol dalam tubuh banyak dilakukan orang dengan cara merubah pola konsumsi makan, menghindari makanan berlemak dan berolah raga secara teratur. Selain itu untuk mengurangi kelebihan kolesterol dalam tubuh dapat dilakukan dengan mengkonsumsi makanan rendah kolesterol.

Salah satu upaya untuk menurunkan kadar kolesterol telur diantaranya dengan menggunakan tanaman herbal. Tanaman herbal dapat berfungsi menurunkan level kolesterol dalam tubuh ternak sehingga akan berpengaruh pada produk-produk peternakan diantaranya 
daging dan telur. Tanaman herbal cukup mudah didapatkan, harganya relatif murah dan aman digunakan sebagai imbuhan pada ransum maupun air minum. Tanaman herbal yang dapat digunakan adalah daun sirih (Piper betle Linn).

\section{MATERI DAN METODE PENELITIAN}

Penelitian ini menggunakan ayam petelur periode layer umur 50 minggu strain Isa Brown dari PT. Anwar Sierad. Ayam petelur yang digunakan sebanyak 250 ekor. Kandang yang digunakan dalam penelitian ini adalah kandang baterai atau cage yang terbuat dari bambu sebanyak 25 buah, dan setiap baterai diisi 10 ekor ayam. Masing-masing kandang dilengkapi dengan tempat pakan dan tempat minum yang memanjang terbuat dari pipa paralon. Setiap baterai pada tempat pakan diberi sekat yang berfungsi agar ayam tidak mengkonsumsi pakan yang ada di baterai lain. Ransum yang digunakan merupakan pakan basal disusun dari konsentrat (SM-204 yang diproduksi oleh PT. Anwar Sierad), jagung dan bekatul. Komposisi ransum terdiri dari jagung 52\%, konsentrat 35\% dan bekatul 13\%. Kandungan nutrisi ransum yang digunakan dalam penelitian ini berdasarkan perhitungan dengan menggunakan program Brill Formulation dapat dilihat pada tabel dibawah ini.

Tabel 1. Kandungan Nutrisi Ransum Ayam Petelur yang digunakan dalam

Penelitian

\begin{tabular}{lc}
\hline Nutrisi & Jumlah \\
\hline Energi Metabolis & $2750 \mathrm{Kkal}$ \\
Protein Kasar & $18,268 \%$ \\
Lemak Kasar & $4,780 \%$ \\
Serat Kasar & $3,0000 \%$ \\
& \\
Asam Amino secara Kasar & \\
Lisin & $0,940 \%$ \\
Metionin & $0,470 \%$ \\
Metionin + Sistin & $0,862 \%$ \\
Trionin & $0,728 \%$ \\
Triptopan & $0,203 \%$ \\
Kecernaan Asam Amino & \\
Lisin & \\
Metionin & $0,780 \%$ \\
Metionin + Sisitin & $0,430 \%$ \\
Treonin & $0,757 \%$ \\
Triptopan & $0,606 \%$ \\
Calcium & $0,174 \%$ \\
Pospor Total & \\
Lavailable & $3,650 \%$ \\
Iodium & $0,800 \%$ \\
Chloride & $0,440 \%$ \\
Abu & $0,150 \%$ \\
Da Prime yang & $0,170 \%$ \\
\hline Siolah (2014) & $5,060 \%$ \\
\hline
\end{tabular}

Sumber : Data Primer yang diolah (2014).

Metode yang digunakan dalam penelitian ini adalah metode eksperimental dengan menggunakan Rancangan Acak Lengkap (RAL) dengan menggunakan 5 kali perlakuan dengan 5 kali ulangan, dan masing-masing ulangan terdiri dari 10 ekor ayam. Adapun perlakuan pada penelitian ini adalah sebagai berikut:

P0 : Pakan Basal

P1 : Pakan Basal $+5 \mathrm{ml}$ jus daun sirih

P2 : Pakan Basal $+7,5 \mathrm{ml}$ jus daun sirih

P3 : $\quad$ Pakan Basal $+10 \mathrm{ml}$ jus daun sirih

P4 : Pakan Basal $+12,5 \mathrm{ml}$ jus daun sirih

\section{Variabel Pengamatan}


Kadar Kolesterol Telur

Pengambilan telur dilakukan pada setiap ulangan sebanyak 25 sampel. Sampel diambil masing-masing tujuh butir telur dari setiap ulangan. Pengambilan telur ini dilakukan pada akhir penelitian. Selanjutnya 25 sampel telur ayam diuji di laboratorium kimia Universitas Muhammadiyah Malang untuk pengukuran kadar total kolesterol.

\section{Analisis Data}

Data yang diperoleh dianalisis dengan sidik ragam Analysis of Varience (ANOVA). Apabila terjadi pengaruh yang nyata atau sangat nyata maka dilanjutkan dengan Uji Duncan untuk mengetahui perbedaan antar perlakuan (Steel dan Torrie, 1993). Model matematikanya adalah :

Keterangan :

$$
Y i j=\mu+\alpha i+\epsilon i j
$$

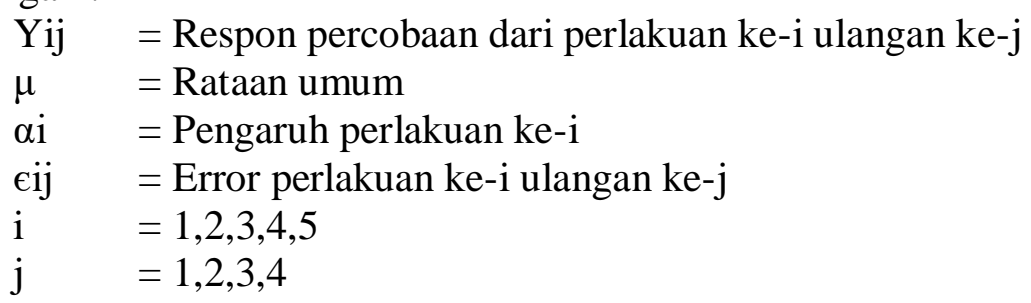

\section{HASIL DAN PEMBAHASAN}

Hasil rata-rata pengukuran kadar kolesterol telur yang diberi perlakuan jus daun sirih disajikan pada tabel dibawah ini.

Tabel 2. Rataan Hasil Kolesterol Total (mg/100 g) Kuning Telur Segar

\begin{tabular}{cc}
\hline Perlakuan & Kolesterol \\
\hline P0 & $448,20 \pm 19,98^{\mathrm{e}}$ \\
P1 & $396,07 \pm 11,90^{\mathrm{d}}$ \\
P2 & $353,77 \pm 6,68^{\mathrm{c}}$ \\
P3 & $328,51 \pm 5,76^{\mathrm{b}}$ \\
P4 & $304,38 \pm 10,85^{\mathrm{a}}$ \\
\hline
\end{tabular}

Keterangan : Hasil Analisis Laboratorium Kimia Universitas Muhammadiyah Malang (2014).

Notasi yang berbeda dalam kolom yang sama menunjukkan perbedaan yang sangat nyata antar perlakuan $(\mathrm{P}<0,01)$.

Data pada tabel 4 menunjukkan rataan kadar kolesterol telur yang diberi perlakuan jus daun sirih berpengaruh sangat nyata $(\mathrm{P}<0,01)$ terhadaap penurunan kadar kolesterol telur. Kadar kolesterol telur pada penelitian ini berkisar antara 304,38-448,20 mg, sedangkan kandungan kolesterol telur berdasarkan USDA (2007) adalah $425 \mathrm{mg}$. Penurunan kadar kolesterol telur pada penelitian ini disebabkan oleh penurunan kadar kolesterol darah ayam petelur. Menurut Rahmat dan Wiradimaja (2011) cara yang dapat dipakai untuk menurunkan kadar kolesterol telur dapat dilakukan dengan menurunkan kolesterol darah.

Penurunan kadar kolesterol darah ayam petelur dipengaruhi oleh beberapa faktor. Faktor pertama, penurunan kadar kolesterol LDL (low density lipoprotein) dalam darah. LDL merupakan lipoprotein pengangkut kolesterol terbesar untuk disebarkan ke seluruh endotel jaringan perifer pembuluh nadi yang mempunyai efek aterogenik, yaitu mudah melekat pada dinding bagian dalam pembuluh darah dan menyebabkan penumpukan lemak yang dapat menyempitkan pembuluh darah. lebih kurang 65\% total kolesterol berada dalam bentuk LDL (Muhtadi dkk, 1993). Penurunan kadar LDL disebabkan karena adanya zat aktif yang terdapat pada daun sirih yaitu flavonoid. Flavonoid merupakan antioksidan polifenol yang mampu memperkuat dinding sel darah merah dan 
mengatur permeabilitasnya, mengurangi kecenderungan trombosit dan menghambat oksidasi LDL sehingga mengurangi proses arterosklerosis pada pembuluh darah. Flavonoid termasuk senyawa fenol alami dan merupakan golongan terbesar, sementara beberapa golongan polimer penting seperti lignin, melanin, dan tanin termasuk polifenol (Suradikusumah, 1989). Senyawa fenol dapat menghambat pembentukan micelle usus tempat terjadinya penyerapan asam empedu yang salah satu fungsinya untuk melarutkan kolesterol melalui saluran empedu ke dalam usus, sehingga pada akhirnya kolesterol tubuh menurun (Kusnadi 2004 dalam Hanafiah, 2009).

Faktor kedua, meningkatnya kadar kolesterol HDL (high density lipoprotein) dalam darah. HDL merupakan lipoprotein yang mengandung Apo A dan mempunyai efek antiaterogenik kuat sehingga disebut juga kolesterol baik. Fungsi utama HDL yaitu mengangkut kolesterol bebas yang terdapat dalam endotel jaringan perifer, termasuk pembuluh darah, ke reseptor HDL di hati untuk dikeluarkan lewat empedu. Dengan demikian, penimbunan kolesterol di perifer berkurang (Muhtadi dkk, 1993). Menurut Mayes et all (1997) meningkatnya HDL akan menurunkan kolesterol, karena kolesterol bebas akan dikeluarkan dari jaringan oleh HDL kemudian diangkut untuk diubah menjadi asam empedu. Partikel HDL berfungsi mengangkut kolesterol dari jaringan adiposa ke organ hati. Kurang lebih 75-80\% kolesterol dalam partikel HDL akan dikonversi menjadi partikel HDL oleh enzim lesitin kolesterol asil transferase (LCTA) untuk diangkut ke hati dan disirkulasikan kembali. Meningkatnya kadar HDL akibat pemberian jus daun sirih dalam ransum dapat mengurangi resiko terjadinya arterosklerosis, penggumpalan darah maupun jantung koroner. Ditambahkan Hanafiah (2009) HDL yang tinggi sebagai antiarterogenik mampu mengangkut kolesterol bebas yang terdapat dalam jaringan perifer, termasuk pembuluh darah ke reseptor HDL di hati untuk dikeluarkan lewat empedu, sehingga kadar kolesterol darah menurun. Peningkatan HDL berkolerasi negatif terhadap resiko menderita arterosklerosis.

Faktor ketiga, penurunan kadar trigliserida dalam darah. Trigliserida adalah suatu jenis lemak yang terdapat dalam darah dan berbagai organ dalam tubuh. Trigliserida merupakan substansi yang terdiri dari gliserol dan asam lemak. Trigliserida dalam darah dapat mempengaruhi kadar kolesterol (Hanafiah, 2009). Pemberian jus daun sirih dapat menurunkan kadar trigliserida dalam darah, hal ini disebabkan oleh rendahnya pasokan asam lemak dari usus. Pasokan asam lemak yang rendah dari usus disebabkan oleh kerja lipase pankreas untuk memecah lemak dihambat oleh flavonoid. Sebelum melakukan tugas membantu penyerapan asam lemak, asam empedu sudah terikat oleh flavonoid dan dikeluarkan dari tubuh dalam bentuk kotoran. Proses digesti lemak dimulai di usus halus oleh lipase pankreas dan garam empedu. Trigliserida dihidrogenasi menjadi asam lemak bebas, 2-monogliserida dan gliserol. Monogliserida dan asam lemak serta garam empedu membentuk micelle untuk diserap melalui brush border pada dinding usus. Micelle yang diserap selanjutnya mengalami pemecahan lagi menjadi asam lemak yang rantainya 10 dan 2-monogliserida. Melalui jalur monogliserida atau $\alpha$-gliserophosphatase, zat ini diresintesis lagi di usus halus menjadi trigliserida. Sebelum melalui membran basal untuk diteruskan ke sistem limphatikus, dibentuk kilomikron yang merupakan gabungan trigliserida (86\%), protein, kolesterol, phospholipid dan vitamin larut lemak (Prawirokusumo, 1994).

\section{KESIMPULAN DAN SARAN Kesimpulan}

Penambahan jus daun sirih pada ransum ayam petelur dengan level yang berbeda $(5 \mathrm{ml}$; $7,5 \mathrm{ml} ; 10 \mathrm{ml}$; dan $12,5 \mathrm{ml})$ berpengaruh sangat nyata $(\mathrm{P}<0,01)$ terhadap penurunan kadar kolesterol telur dibandingkan dengan kontrol, penurunan kadar kolesterol telur pada penelitian ini ditunjukkan dengan semakin tinggi volume jus daun sirih yang ditambahkan pada ransum ayam petelur ada kecenderungan semakin tinggi pula penurunan kadar kolesterol telur. 


\section{Saran}

Perlu dilakukan penelitian lanjutan mengenai level penambahan jus daun sirih pada ransum ayam petelur, sehingga dapat dihasilkan nilai maksimal dalam penurunan kadar kolesterol telur.

\section{DAFTAR PUSTAKA}

Ahmad dan Suryana, I. 2009. Pengujian Aktivitas Ekstrak Daun Sirih (Piper betle Linn) Terhadap Rhizoctania sp Secara In Vitro. Departemen Management Hutan Fakultas Kehutanan Institut Pertanian Bogor. Bogor.

Apriansyah, B. B., 2010. Pengaruh Pemberian Jamu Ternak Terhadap Kadar Kolesterol dan Profil Darah Ayam Arab (Gallus turcicus). Departemen Ilmu Nutrisi dan Teknologi Pakan Fakultas Peternakan. Institut Pertanian Bogor. Bogor.

Bappenas. 2010. Beternak Ayam Petelur. http://www.ristek.go.id. Diakses tanggal 5 mei 2013.

Hanafiah, T.H. 2009. Kadar Kolesterol Darah Ayam Petelur Yang Diberi Rebusan Daun Sirih. Program Studi Ilmu Nutrisi dan Makanan Ternak Fakultas Peternakan. Institut Pertanian Bogor. Bogor.

Hembing. 2006. Mengendalikan Kolesterol Tinggi Dengan Herbal Dan Pola Hidup Sehat. http://portal.cbn.net.id (11 Desember 2011).

Heyne, K. 1987. Tumbuhan Berguna Indonesia. Jilid II. Badan Litbang Kehutanan Jakarta. Hal: 622-627.

Mahendra, B. 2005. 13 Jenis Tanaman Obat Ampuh. Cetakan 1. Penebar Swadaya. Jakarta.

Mayes, P.A., R.K. Murray, D.K. Granner and V.W Rodwell. 1997. Biokimia Harper. 24 ${ }^{\text {th }}$ Edition. Terjemahan: Hartono, A. Penerbit Buku Kedokteran. EGC. Jakarta.

Moelyanto dan Mulyono. 2004. Khasiat dan Manfaat Daun Sirih Obat Mujarab dari Masa ke Masa. Edisi I. Agromedia Pustaka. Jakarta.

Muchtadi, D., N. S. Palupi dan M. Astawan. 1993. Metabolisme Zat Gizi. Pustaka Sinar Harapan. Jakarta.

Pilliang, W.G., dan S. Djojosubagio. 2006. Fisiologi Nutrisi. Vol. 1. Edisi Revisi. IPB Press.

Prawirokusumo, S. 1994. Ilmu Gizi Komparatif. Edisi Pertama. BPFE. Yogyakarta.

Puspitasari, J, D. 2012. Uji Efek Antiflamasi Ektrak Air Campuran Daun Sirih (Piper Betle Linn), Gambir (Uncaria gambir R), dan Kapur Sirih (CaO) secara Invivo. Program Studi Farmasi Fakultas Kedokteran dan Kesehatan. Universitas Negeri Syarif Hidayatullah. Jakarta. 
Rahmad. D., dan R. Wiradimaja. 2011. Pendugaan Kadar Kolesterol Daging dan Telur Berdasarkan Kadar Kolesterol Darah pada Puyuh Jepang. Fakultas Peternakan : Universitas Padjajaran.

Rosman, R dan S. Suhirman,. 2006. Sirih Tanaman Obat yang Perlu Mendapat Sentuhan Teknologi Budaya. Warta Penelitian dan Pengembangan Tanaman Industri, Vol 12 (1) : 13-15.

Soeharno, I. 2002. Serangan Jantung dan Stroke. Jakarta : PT. Gramedia Pustaka Utama.

Steel, R.G.D., dan J.H. Torrie. 1993. Prinsip dan Prosedur Statistika Suatu Pendekatan Biometrik. Terjemahan: M. Syah. Gramedia Pustaka Utama. Jakarta.

Suradikusumah, E. 1989. Kimia Tumbuhan, Bahan Pengajaran. Depdikbud-Dirjen penti-PAU Ilmu Hayat. Institut Pertanian Bogor. Bogor.

Susanto, H. 2006. Jaringan Kadar Kolestrol Tinggi. Harian Fajar, Makassar.

Tetty. 2003. Puyuh : Si Mungil Penuh Potensi. Cetakan Kedua. Agro Media Pustaka. Jakarta.

Tillman, Hartadi, Reksohadiprodjo, Prawirakusumo, dan Lebdosoekodjo. 1986. Ilmu Makanan Ternak Dasar. Gajah Mada University Press. Yogyakarta. 